\title{
Profile of micro small and medium powerloom enterprises of Ludhiana city
}

Received: 20.12.2017; Revised: 17.04.2018; Accepted: 05.05.2018

See end of the paper for authors' affiliations

\section{Garima Singh}

Department of Apparel and

Textile Science, Punjab

Agricultural University,Ludhiana

(Punjab) India

Email : gsingh1505@gmail.com
ABSTRACT : The powerloom industry in Punjab provides employment to a large number of skilled and semi-skilled workers and is reputed for its powerloom weaving. The state produces large volumes of powerloom products that find a market not only in India but foreign countries as well. The present study was conducted to document the profile of micro, small and medium powerloom enterprises of Ludhiana district of Punjab using survey method. The sample consisted of 128 MSMEs which comprised of fifty micro powerloom units, seventy-six small powerloom units and two medium powerloom units. All the micro and medium powerloom enterprises were included in the sample due to their limited total number in the list of enterprises whereas purposive probability proportional to size sampling technique was employed to select small enterprises. Largest percentage of owners of micro enterprises $(64.06 \%)$ were 45-65 years in age, while 43.42 per cent owners of small enterprises were $45-55$ years old followed by 30.26 who were 55-65 years old. Though the highest percentage of the owners $(48.00 \%)$ of micro enterprises were educated upto graduation level but a large segment (46.00\%) of micro enterprises was run by matriculate pass owners. Thus, micro enterprises were also being run successfully by owners who never went to college. Maximum percentage of the MSMEs (32.81\%) were established during 1985-1995, while in comparison, a lower percentage of powerloom enterprises (12.50\%) had established in during 2005-2015. Steep rise in the establishment of small enterprises was observed during 1985-1995. After 2005, there has been a sharp decline in this trend. Majority of the MSMEs (90.62\%) were located in independent industrial areas of Ludhiana city. While the rest of the enterprises were located in the industrial cum residential areas. A highest percentage of the MSMEs $(49.21 \%$ ) were found to be managed by owners.

KEY WORDS: Powerloom, Micro, Small, Medium enterprises

- HOW TO CITE THIS PAPER : Singh, Garima, Brar, Kanwaljit Kaur and Kapila, Prerna (2018). Profile of micro small and medium powerloom enterprises of Ludhiana city. Asian J. Home Sci., 13 (1) : 295-303, DOI: 10.15740/HAS/AJHS/13.1/295-303. Copyright@ 2018: Hind Agri-Horticultural Society. 